Cahiers $d u$ MONDE RUSSE

\section{Cahiers du monde russe}

Russie - Empire russe - Union soviétique et États indépendants

\title{
Why Was Russian Direct Rule over Kyrgyz Nomads Dependent on Tribal Chieftains "Manaps" ?
}

Pourquoi l'administration directe russe sur les nomades kirghiz était-elle dépendante des manaps ou chefs tribaux?

\section{Tetsu Akiyama}

\section{(2) OpenEdition}

Journals

Electronic version

URL: http://journals.openedition.org/monderusse/8212

DOI: $10.4000 /$ monderusse. 8212

ISSN: $1777-5388$

\section{Publisher}

Éditions de l'EHESS

\section{Printed version}

Date of publication: 1 October 2015

Number of pages: 625-649

ISBN: 978-2-7132-2507-9

ISSN: $1252-6576$

Electronic reference

Tetsu Akiyama, «Why Was Russian Direct Rule over Kyrgyz Nomads Dependent on Tribal Chieftains " Manaps" ? ", Cahiers du monde russe [Online], 56/4 | 2015, Online since 01 October 2018, Connection on 01 May 2019. URL : http://journals.openedition.org/monderusse/8212 ; DOI : 10.4000/ monderusse. 8212

This text was automatically generated on 1 May 2019.

(c) École des hautes études en sciences sociales 


\title{
Why Was Russian Direct Rule over Kyrgyz Nomads Dependent on Tribal Chieftains "Manaps"?
}

Pourquoi l'administration directe russe sur les nomades kirghiz était-elle dépendante des manaps ou chefs tribaux?

\section{Tetsu Akiyama}

\begin{abstract}
During the subjugation of Ferghana forty-one years ago, the Kirgiz [i.e. Kyrgyz], who are now roused into action, crossed over the mountains to Ferghana with their renowned leader Lieutenant

Colonel Shabdan Dzhantaev, and assisted [the Russian officer M.D.] Skobelev in the subjugation of the population that had settled there. Letter of the Governor-General of Turkestan A.N. Kuropatkin to the War Minister of the Russian Empire, dated 16 August $1916^{1}$
\end{abstract}

1 In historical research of the Russian Empire, which has flourished since the collapse of the Soviet Union, it has been argued that Russian rule had a pluralist character. While Russian authorities did attempt to propagate Russian Orthodox Christianity and the Russian language, they did, on the whole, pursue co-existence with local cultures and religions in a somewhat ambiguous manner. ${ }^{2}$

2 It was not that there were positive reasons for the Russian Empire to wholeheartedly adopt a pluralist policy. More accurately, there were negative reasons for doing so, including the limitations of Russian governing prowess and assimilative power. Central Asia is a particularly conspicuous example of such a phenomenon. In his disquisition into Russia's propagation of Russian Orthodox Christianity and introduction of conscription in Central Asia, Tomohiko Uyama makes the following assertion: 
Russian military and civil officials were fundamentally sceptical about the population of Central Asia. Therefore, rather than advancing a policy of Russification unreasonably, they attempted to maintain a passive stability." ${ }^{3}$ it failed to make substantive progress towards such a goal. This is evidenced by the fact that throughout the time of the Russian Empire, the subject population of Central Asia had the legal status of inorodtsy [aliens]. Indeed, a significant gulf lay between Russian settlers and locals in terms of religion, culture, and language.

Against this backdrop of partial integration, one must consider the people who operated between the Russian Empire and local communities. The role of the "collaborator" under imperial rule has already been a subject of attention in historical research on Western imperial expansion in Asia and Africa. ${ }^{4}$ Recent development in the history of the Russian Empire has shed some light on those who played similarly collaborative roles under the Russian rule. As for the specific people who mediated between the Russian Empire and Central Asia, it is well known that the Tatars of the Volga-Ural region played such a role. ${ }^{5}$ Studies have also identified collaborators among the local populations of Central Asia.

5 These local collaborators can be broadly divided into two groups. The first were the modern educated class, the so-called "intellectuals." The second were the traditional local elites. Of the two, the former have been researched the most, though there has been a sudden increase in interest in the traditional local elites. It is an unmistakable fact that Russian imperial rule would not have been possible, had it not been for the collaboration of such elites. Research from this standpoint is making forward strides. Research on the settled areas of Central Asia is making the most progress, ${ }^{6}$ but there are also interesting findings concerning the situation among nomads, particularly the Kazakhs. ${ }^{7}$ Still, research that attempts to construe a more positive analysis of local traditional elites, such as the nomads of Central Asia under the Russian imperial rule, remains as inadequate as ever.

6 In view of this inadequacy, this paper will focus on the chieftains of the Kyrgyz nomads, who inhabited the highland areas of the Tian Shan Mountains. During the late 19th and early $20^{\text {th }}$ centuries, the intellectuals among the Kazakhs and the Uzbeks had gradually asserted themselves as the leaders of their society. By comparison, the appearance of the Kyrgyz intellectuals came extremely late. Until the early $20^{\text {th }}$ century, chieftains of the tribes-known as manaps ${ }^{8}-$ continued to have a strong presence as the substantial leaders of Kyrgyz society.

7 Recent studies have been made on the manaps under Russian rule. For example, Daniel Prior has analysed an epic poem dedicated to one of the prominent figure among the manaps Shabdan Jantay uulu (1840-1912). ${ }^{9}$ In addition, I considered the activities of the manaps, including Shabdan, from the perspective of both traditional nomadic values and Islam. ${ }^{10}$

8 Although studies on the internal activities of manaps have been conducted in this vein, so far the policy of the Russian Empire toward the manaps has been superficial. When the Russian Empire annexed and amalgamated non-Russian people, it generally used local elites including tribal chieftains as collaborators. Indeed, in the mid-19 $9^{\text {th }}$ century, preceding the military expansion into the heart of Central Asia, the Russian Empire developed collaborative relationships with the manaps and acknowledged their official position. ${ }^{11}$ According to the recent work of Daniel Prior, concomitant to this collaboration, the Russian Empire expected to find a class analogous to the Kazakh sultans 
amongst the Kyrgyz; this had the effect, consciously or unconsciously, of creating or strengthening an aristocratic layer in Kyrgyz society. ${ }^{12}$

However, the position of manaps as local collaborators was to change completely after the establishment of the Governor-Generalship of Turkestan in 1867. The change came about because of the establishment of Russian direct rule in the same year, after which manaps were no longer officially recognised as collaborators. Nevertheless, there is an overwhelming body of evidence, including testimonies from contemporaries asserting that manaps continued to hold important positions throughout the imperial period, despite the imposition of Russian direct rule. While ethnologist M.F. Gavrilov, who studied Kyrgyz nomads during the 1920s, acknowledged that the shift to direct rule in 1867 had an impact on them, he argued that throughout the imperial period, "the office of manap (manapstovo) remained rigidly intact, and took on a somewhat monolithic form." 13

10 Why was it that, even into the $20^{\text {th }}$ century, this traditional chieftain class, though not officially recognised under Russian rule, did not dissolve and in fact continued to hold a powerful influence? As we have seen, one reason for this may be found by examining their activities, including the compilation and publication of genealogies and heroic epics, as well as Islamic acts. Another reason might be the quality of Russian rule itself at the time. The fact that manaps continued to exist under Russian rule, albeit without official recognition, was most likely due to the weak governing ability of the Russian Empire, including the general dissonance within the Russian ruling establishment and interagency disagreements over the treatment of manaps.

11 From such a point of view, this article will look at the way Russian military authorities dealt with manaps during the half century of its direct rule following the establishment of the Governor-Generalship of Turkestan in 1867. Past studies start and end by simply summarizing the system of rule. ${ }^{14}$ Therefore, this article will focus on the area of Tokmak uezd (renamed Pishpek uezd in 1888), and Przheval'sk uezd in the southern part of Semirech'e oblast, and discuss how Russian military authorities positioned manaps during the following three periods: 1) from 1867 to the early 1880s, when political reforms were facilitated along with the military expansion into Central Asia; 2) from 1880s to 1905, when Russian direct rule was developed; 3) from 1905 to 1916, when Semirech'e oblast was positioned as the target of the Russian peasant colonization under the initiative of the central government. The principal materials used for this article include the official documents of the Russian military authorities currently stored in the national archives of Kazakhstan (TsGA RK), Uzbekistan (TsGA RUz), Kyrgyzstan (TsGA KR), and Russia (RGIA, RGVIA). To supplement these sources, I also refer to official gazettes, newspapers, and magazines published during the periods in question.

\section{Manaps between political reform and military expansion}

12 Following the establishment of the Governor-Generalship of Turkestan, Central Asia was put under a system of Russian direct rule. It is well known that the decision to take this measure had been affected by the spirit of the so-called "Great Reforms" advanced from above in the central part of the empire. ${ }^{15}$ In fact, the Governor-Generalship was composed of the same administrative units used for the governance of peasants, namely "oblasts", 
"uezds", and "volosts". In this process, governance of the native population, who were to be organized into volosts, would be restructured in line with the principle behind the Great Reforms: the equalization of existing social groups. In other words, in place of local existing tribal chieftains such as manaps, volost administrators (volostnoi upravitel') elected by the "common people (narod)" would act as the new official intermediaries for Russian direct rule. ${ }^{16}$ Volost administrators were placed under the command of uezd commanders (uezdnyi nachal'nik), who were all ethnically Russian. In other words, volost administrators were local government officials responsible for colonial rule at a grassroots level, whose main responsibility was to implement directives from the Russian military authorities.

Map 1 - The Semirech'e oblast in its regional context (19th century)

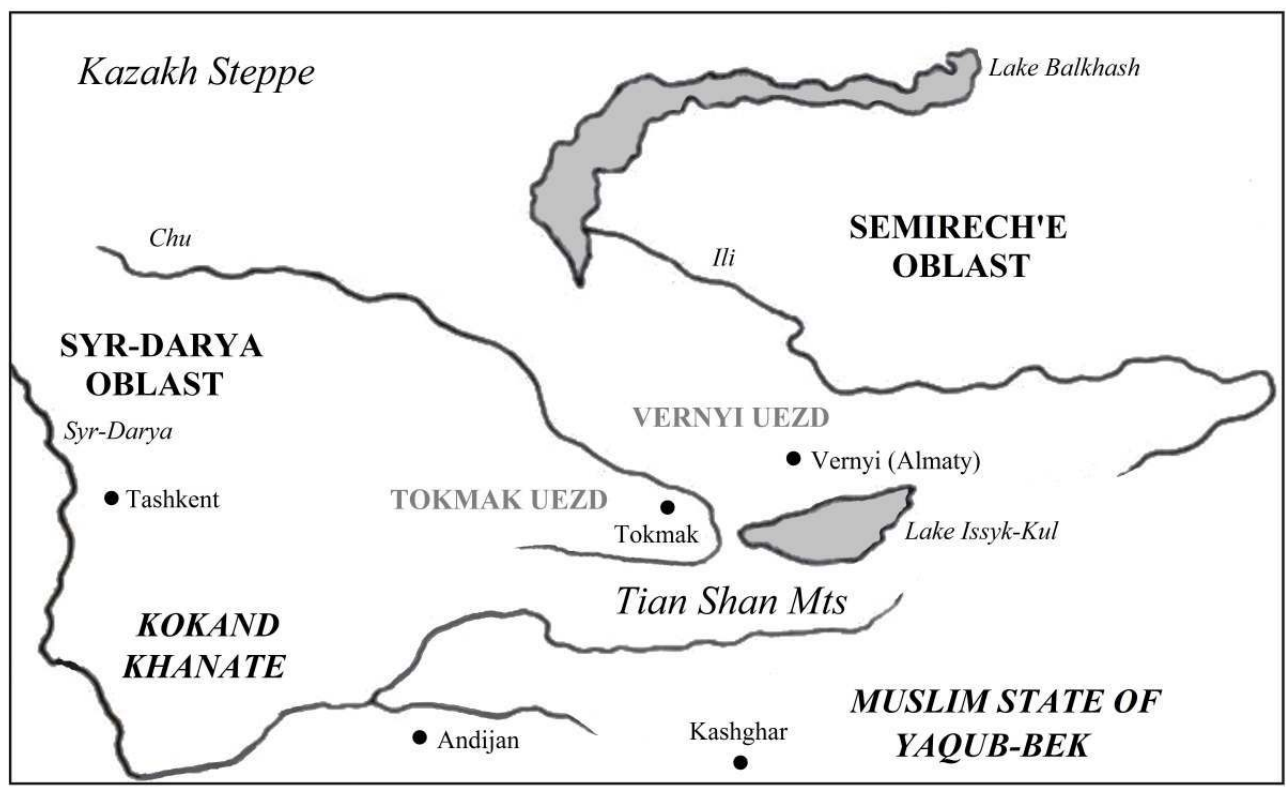

(C) TETSU AKIYAMA

However, the situation in Semirech'e oblast at the time, particularly in the area around the Tian Shan mountain range inhabited by Kyrgyz nomads, was not so straightforward as to allow the unitary implementation of the Great Reforms as in the central part of the empire. Not only had the region itself only just been conquered, it also was adjacent to the Khanate of Kokand (1709-1876), one of the Islamic states in Central Asia based in Ferghana valley. It was therefore a highly significant region in terms of being a site for further military expansion of the Russian Empire.

For this reason, it was essential for Russian military authorities to maintain the status quo in the region and establish a defence network in order to tackle the threat of attack from outside. ${ }^{17}$ Thus, rather than actively interfering in the lives of Kyrgyz nomads and removing manaps, Russian military authorities, in particular the first Tokmak uezd commander G. Zagriazhskii, continued their attempts to use manaps as intermediaries. Indeed, the fact that manaps were elected as volost administrators in all 14 of the Kyrgyz volosts established in the Tokmak uezd from 1867 to 1868, appears to be due in no small part to the will of the uezd commander. ${ }^{18}$

Furthermore, Zagriazhskii gave manaps unofficial posts outside the framework of the official volost system. He gave a particularly important position to Shabdan, a manap of 
the Tïnay branch of the Saribagïsh tribe. Until the late 1870s, Shabdan and his retainers ( zhigit) had cooperated with the military expedition of the Russian Empire. ${ }^{19} \mathrm{He}$ had also acted as a mediator in Russia's efforts to foster communication with Kyrgyz nomads living around Tokmak uezd. The importance of his position is also evidenced by a petition sent in 1876 from a Kyrgyz of the Saribagish volost to the first Military Governor (Voennyi Gubernator) of Semirech'e oblast G.A. Kolpakovskii, which read:

If you are the governor of Almatï [i.e. Vernyi: the capital of Semirech'e oblast], then

Shabdan is as if he were the governor of Kyrgyz of Tokmak uezd. ${ }^{20}$

If we take into account such a situation, the following assessment (made by the Governor-Generalship of the Steppes in 1884) is not always exaggerating: "Russian uezd commander cannot replace manap-patriarch. [...] He could not rise to the position of manap-patriarch. ${ }^{21}$

However, while the Tokmak uezd commander viewed manaps as important mediators, there were attempts made within the oblast Government of Semirech'e, particularly by the Military Governor Kolpakovskii, to faithfully follow the principles of the new regime. Kolpakovskii had in fact expressed his dissatisfaction that all of the men elected as volost administrators were manaps, saying,

The common People have learnt nothing about the use of the rights they have received from the new political settlement, and they do not understand the rules of election..$^{22}$

In view of this situation, Kolpakovskii had tried to organize briefing meetings for the common people in various areas of the oblast. He hoped that persistent explanations would ultimately allow them to supersede the "tribal principle (rodovoe nachalo)" by a "highly advanced Russian civilization."23

19 Kolpakovskii also harboured reservations about the close relationship between Shabdan and the Tokmak uezd commander Zagriazhskii. For example, when Zagriazhskii sent Shabdan on a fact-finding mission to the mountainous region bordering the Khanate of Kokand in 1869, Kolpakovskii ordered Zagriazhskii to verify the information, stating the following:

My many years of experience have given me an extremely negative view of the level of sincerity possessed by Kirgiz [i.e. Kazakh and Kyrgyz], and Shabdan is no exception. ${ }^{24}$

20 Another example concerned the "Special congress of people's judges (Chrezvychainyi s" ezd narodnykh sudei)" in the same year, they held to resolve disputes between Kyrgyz subject to the Khanate of Kokand, and Kyrgyz subject to the Russian Empire. According to the 200 th clause of the "Temporary Statute for the Administration of the oblasts of Semirech'e and Syr-Darya", which was instituted in 1867, it was strictly prohibited for officials to intervene in the arbitration. ${ }^{25}$ When it came to light that Shabdan, who acted as the uezd commander's proxy at the congress, had forcefully intervened in the arbitration, Kolpakovskii claimed that "if such practice is left to take its course without any censure, it will take root more deeply and inflict grave damage on the mission of the Russian authority". He then accused Shabdan of being "a dangerous individual upon whom the uezd commander [i.e. Zagriazhskii] is placing too much confidence." ${ }^{\prime 26} \mathrm{He}$ repeatedly urged the first governor-general of Turkestan, K.P. Von Kaufman, to impose a punishment. 


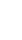

of the new tsar Alexander III in Moscow in 1883, as it was the manaps who were selected from the Tokmak uezd as candidates to attend the coronation: Shabdan from the Saribagïsh tribe, Baytik from the Solto tribe, and Chnï from the Sayak tribe..$^{28}$ of these candidates, Shabdan was sent to the coronation. Prior to his departure to Moscow, a ticket (bilet) of admission to the coronation was sent to Shabdan from the Asiatic department of the Russian Army General Staff. On the other side of the ticket, the words " Kirgiz Manap" were written clearly (Figure 1). ${ }^{29}$

\section{Figure 1 - The other side of the ticket of admission to the coronation of Alexander III sent to Shabdan}

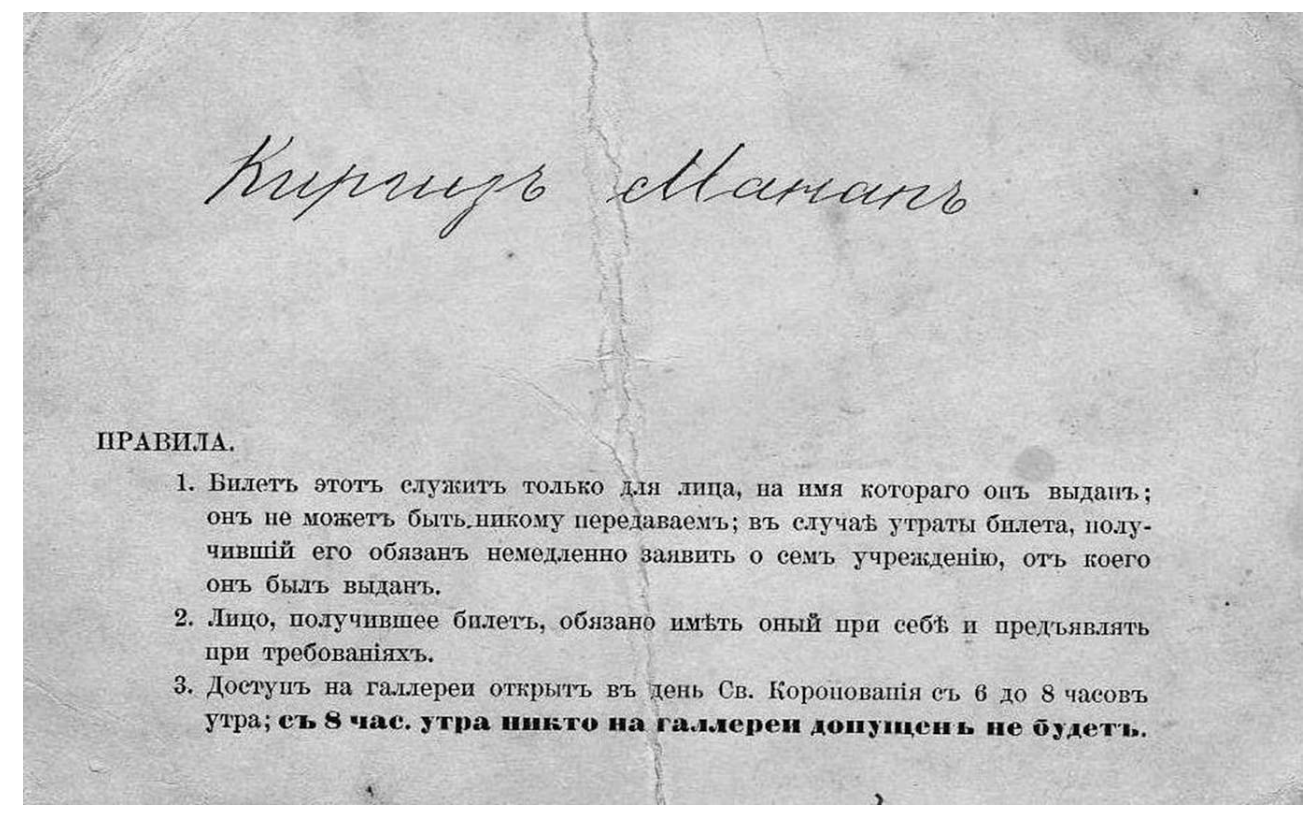

At the same time, we should not forget that at the coronation he was granted the military title of "Lieutenant Colonel (Voiskovoi Starshina)." While the granting of a military title to local elites of Central Asia was by no means unprecedented for the Russian Empire, a government decree dated April 1867 prohibited conferring military titles on Asian "aliens (inorodtsy)" with low "civic value (grazhdanstvennost')", in order not to encourage their "bellicoseness (voinstvennost')." ${ }^{30}$ In fact, when a Russian adjutant Kh. Nazarov applied Kolpakovskii for granting Shabdan a title of officer in 1880, Kolpakovskii refused the 
request according to the 1867 decree. ${ }^{31}$ Although it still remains unknown why Shabdan was granted a military title in spite of the decree, it is assumed that it was realized at the express wish of Russian officers who had participated in the conquest of Central Asia. ${ }^{32}$ In any case, the traditional pattern of awarding a military title to a traditional chieftain was repeated in contradiction to the spirit of direct rule, which aimed to put common people in charge of the government and raise civil engagement.

\section{Manaps as the aristocrats of Kyrgyz}

Under Russian direct rule, not only did Russian military authorities assign manaps as mediators, they also began to recognize them as "aristocrats" unique to Kyrgyz. To examine this point, it is necessary to go further back in history. Russian military officials responsible for governing the periphery of the empire based their attitude toward Kyrgyz on existing attitudes on the social structure of Kazakh nomads. These officials were well aware that Kazakhs were controlled by the "white bone (aqsüyek)" element, including khans, descendent through the male line of Genghis Khan and sultans of the same family. As the Russian Empire accelerated its advance into the Kazakh steppe from the mid-18 century onwards, Russian military officials grew increasingly aware of Kyrgyz as an ethnic group that resided in the periphery of the Kazakh steppe. Accordingly, the absence of the "white bone" or that aristocratic element among the Kyrgyz came to be a defining characteristic of their social structure. Indeed, a Russian geographer P.P. Semënov, who had been creating a survey in the Tian Shan mountain range in the mid-1850s, said that, " manaps are not considered to be an aristocrat akin to the "white bone", that is to say, to sultans of Kazakhs." ${ }^{33}$ Such a perception was largely shared among Russian military officials until the early 1870 s. $^{34}$

However, with the establishment of direct rule from 1867, manaps began to be seen as an aristocratic element unique to Kyrgyz. One individual that vividly illustrated this change in attitude was Zagriazhskii. Aside from his actual political duties as uezd commander, he was also a typical "military orientalist (voennyi vostokoved)" involved in collecting ethnographies. ${ }^{35}$ In his work on the customary law of Kazakhs and Kyrgyz, he states the following:

Generally speaking, Kirgiz [i.e. Kazakhs and Kyrgyz] can be divided into the people of the black bone (chërnaia kost') and the people of the white bone (belaia kost'). [...] Sultans and manaps consider themselves to be of the white bone. Sultans consider themselves the descendants of khans of Kirgiz [i.e. Kazakhs], who in turn are the descendants of Genghis Khan, and manaps consider themselves the descendants of Tagay. ${ }^{36}$

Noteworthy here is how "Tagay", the legendary ancestor of the Kyrgyz tribes, is directly linked to manaps. References to Tagay already appear in accounts of the early 1850s, but in none of these was there even one case where he was directly linked to manaps. ${ }^{37}$ From the 1870s onwards, paralleling the quote above, manaps came to be known as "Tagay's descendants" and recognized as a group that was based on a hereditary principle. As such, they came to be positioned as their own "white bone" (i.e. aristocrat) of Kyrgyz, on par with sultans of Kazakhs. Although the extent to which this new attitude mirrored Kyrgyz's own is unclear, based on various remarks this new awareness took root among Russian military officials and scholars from the early $1870 \mathrm{~s}^{38}$ As expected, Shabdan's "service record (posluzhnoi spisok)" that was made when he was granted the military 
title of Lieutenant Colonel in 1883, stated under his "family background" that he was a " manap (title equivalent to sultan or aristocrat)." ${ }^{39}$

Despite not giving them official recognition, Russian military authorities nevertheless continued to use manaps as mediators, and increasingly acknowledged them as the aristocrats of Kyrgyz. In other words, it would be better to say that the Russian military authorities did not so much undermine the influence of manaps, as managed to reorganize and construct them as a ruling class of Kyrgyz.

\section{Manaps as the target of "struggle (bor'ba)"}

The attitudes of Russian military authorities toward manaps began obviously to change from the beginning of the 1880s. Having accomplished military expansion across Central Asia, Russian military authorities intended to penetrate inside the region of the Kyrgyz nomads. Throughout this process, while Russian military authorities began to indicate a more positive stance toward the protection of the "common people (narod)," manaps came to be seen as an impediment to the colonial rule.

In order to understand this attitude, we will begin by considering the special assembly of the people's court that was held in Pishpek in 1884. To that assembly, not only people's judges (narodnyi sud'ia, bi) but also manaps were invited, to determine the "customs" that the people's court would rely on for its judgment. In the session, a provision mandating that "the debts of the poor should be paid by communities and relatives on their behalf" was proposed. ${ }^{40}$ However, Pushchin, the Tokmak uezd commander at the time, did not accept the proposal. There remain many uncertainties as to the details of this measure, but it may have been the case that Pushchin was trying to prevent a situation in which manaps used the provision to offload their debts onto the shoulders of the common people.

In fact, around the same time, Russian military authorities received many petitions from the common people complaining about being forced to pay the debts of manaps. ${ }^{41}$ The response from Russian military authorities to this situation demonstrates how they viewed manaps at the time. For example, in response to a petition sent from the Saribaghïsh volost in 1888, the Military Governor of Semirech'e oblast G.I. Ivanov issued the following directive to the Tokmak uezd commander:

According to rumours, Shabdan reimburses his debts with camels owned by the common people. I am now firmly convinced that Shabdan is exploiting his position as a manap and is laying his financial burdens squarely on the shoulders of the common people. [...] You must inform Shabdan that collecting taxes or the equivalent for the benefit of manaps is completely forbidden by law. You must also conduct a covert investigation of the activities that Shabdan carries out among the common people. . $^{22}$

This directive suggests that Russian military authorities viewed manaps as exploiters of the common people and were making active efforts to safeguard their interests by keeping manaps in check. From the late 1890s onwards, such an approach became known as the "struggle (bor'ba)" against manaps, which is the focus of this chapter. 


\section{The situation around the anti-manap struggle} report sent to the Military Governor Ivanov in November 1896, Talyzin writes about his own struggle against manaps as follows:

[...] Slowly but surely, the idea that it is possible to appeal against the tyranny of manaps is taking root amongst the common people. [...] Ever since I took up this post, I have systematically engaged in the struggle against manaps. I manage to explain to the common people that linages of manaps are no different from that of other Kirgiz [i.e. Kyrgyz]. I have also prepared cases concerning the petitions against manaps, but since their grip over the people remains as strong as ever, many of the petitions end in defeat. ${ }^{43}$

Attached to this report was a reference document titled "List of names of the native executives and manaps of Pishpek uezd who were indicted for corruption between 1894 and 1896, for collecting taxes from the common people." ${ }^{44}$ The document outlined the course of the investigation and the results of 132 cases, many of which had been aborted midway, and out of which not one manap had ever been found guilty.

This way of educating the common people and creating suits against manaps was not a successful project in the anti-manap struggle, mainly because petitions were difficult to substantiate. As Talyzin points out, the common people were not willing to disclose any information to him:

[...] Throughout my five years of service, I have attempted to gather evidence to substantiate the rumour amongst the common people that manaps collect taxes from them. However, I could not find a single person who was prepared to give witness. The only response I have ever gotten is "We have nothing to petition for. Everything is fine." ${ }^{45}$

Given this situation, while Talyzin was calling for the struggle against manaps, he did not always break off a relationship with manaps including Shabdan. In reality, it is impossible to ignore the role played by manaps as arbitrators. Even Talyzin admitted that Shabdan proved very useful in arbitrating cases of "factional infighting (partiinaia bor'ba)" that was used to occur in election of volost administrator. ${ }^{46}$ In fact, in 1892 Talyzin sent Shabdan to intervene in a case of factional infighting that had broken out in mountainous region in the south of Pishpek uezd. ${ }^{47}$ In addition to this, among the manaps of comparatively younger generation, there were those who were taken into the Russian military government. Indeed, under Talyzin two young manaps served: Mukhamed-Ali-Mulatalin and Diur Sooronbaev. The former worked as a translator (pis'mennyi perevodchik) and in 1895 he was appointed as a collegiate (kollezhskie registratory). ${ }^{48}$ As for the latter, though unofficially, Diur Sooronbay served as an important collaborator, especially for a school building program. Russian-native schools (Russko-kirgizskie shkoly), the first of which was built in Tashkent in the mid-1880s, came to the Kazakh steppe and Semirech'e at the end of the $19^{\text {th }}$ century ${ }^{49}$ In 1896 , there was a plan to build a Russian-native school in Pishpek uezd, where Kyrgyz nomads lived. The construction of the school required large sums of money, but the funds were raised by appointing powerful manaps including Diur to act as assistants..$^{50} \mathrm{An}$ article in the "Newspaper of the Steppe Region (Dala Walayatïning Gazeti)" printed in September 1897 and titled "News from Pishpek", described manaps as "an undesirable phenomenon" and denounced them as men who stood in the way of the school building project. ${ }^{51}$ The reality, however, was that the school project was driven 
forward thanks to the cooperation of the manaps. Thus, it seems that Talyzin's anti-manap struggle was ultimately "superficial posturing."

\section{Exile of manaps exposes the weakness of Russian rule}

The anti-manap struggle did not take the same form throughout the region. Indeed, in the mountainous region (zagornaia storona) running from the Kyrgyz Ala-too mountains to the frontier region of Qing China, for example, things were different. Although this region had already been incorporated into Russian rule by the time the Governor-Generalship of Turkestan was established in 1867 , the Russian population here remained extremely small, even at the end of the nineteenth century. This is because the region was an "isolated corner of land" effectively beyond the reach of Russian surveillance. In an attempt to gain control there, the Russian Empire enhanced its surveillance over the region in 1895 by setting up the At-Bash district (uchastok). ${ }^{52}$

Map 2 - Administrative geography of Kyrgyz territory under Russian rule

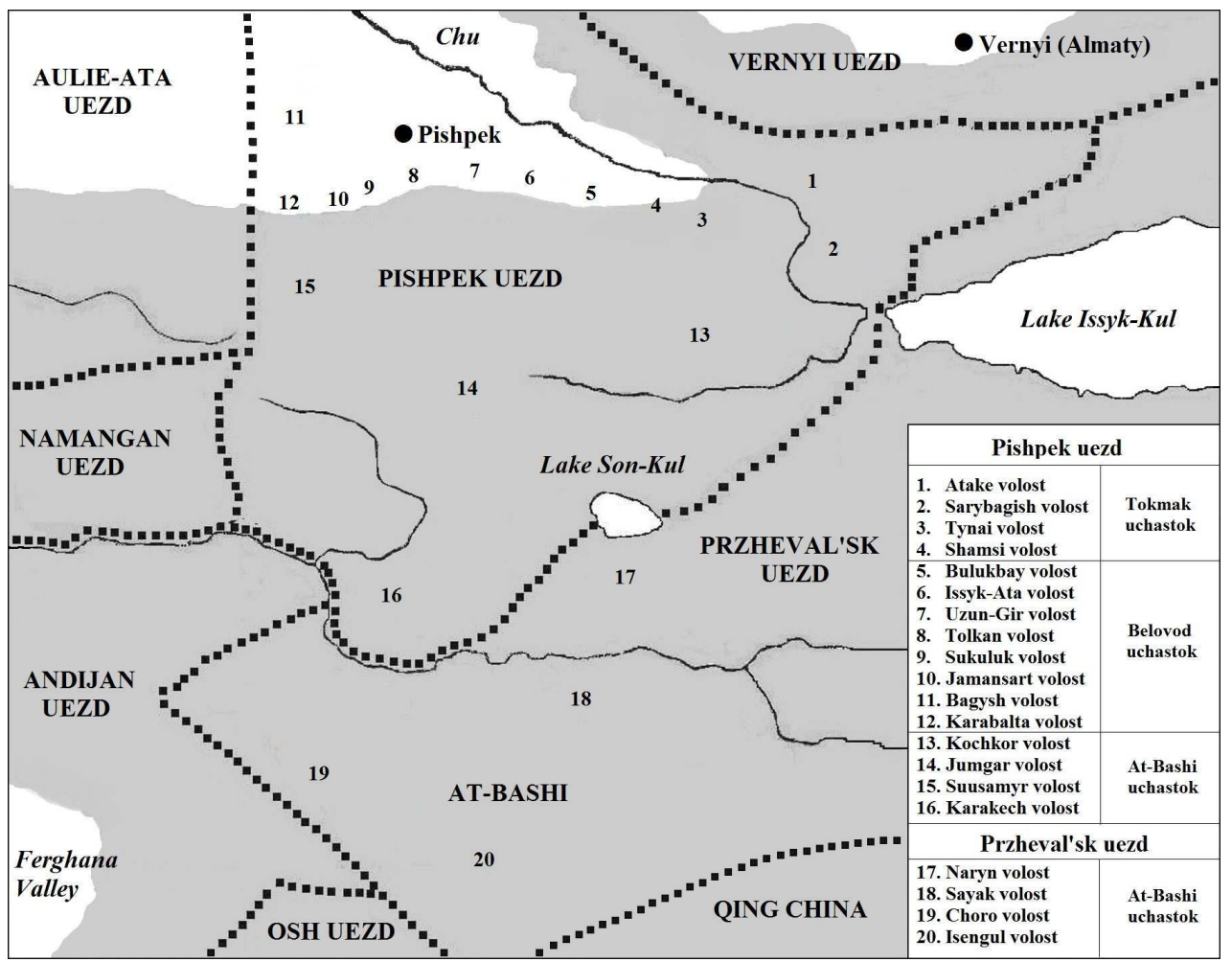

(C) TETSU AKIYAMA

A leading figure who advanced the anti-manap struggle in this region was the Commander of the At-Bash district. As can be seen in the following quotation, he was deeply suspicious not only of manaps, but also of the native colonial organization itself:

Manaps have become accustomed to the local legal system, which provides Kirgiz [i.e. Kyrgyz and Kazakhs] autonomy and a people's court, and they have formed a tight organization (strogaia organizatsiia). This organization is an obstacle that stands between the common people and Russia. By manipulating the people's court and the local administrative institutions to serve their own interests, manaps are continuing to hold the common people in, what is in reality, the very same condition of slavery that they were in before [Russia's] conquest. ${ }^{53}$ 
gside the strengthening of a system of surveillance, the Commander of the At-Bash district sometimes exercised tougher measures, including the exile (vyselenie) of manaps. The Commander thought that in order to completely dismantle the "obstacle" that manaps created by exploiting the local administrative system, it would be necessary to physically remove them. Contrary to such a tough attitude, the central Tsarist government was lukewarm towards the idea of exile. When it was requested, ${ }^{58}$ the Ministry of Internal Affairs refused to give consent, stating that, "the matter can be settled within the framework of local government authority and general law and order." 59 In response, the governor-general of Turkestan complained about "the lack of forces, staff, and money necessary for carrying this out," ${ }^{60}$ and he succeeded in persuading the ministry to consent to the exile of two manaps who wielded considerable influence in the mountainous region. One of these manaps was Choko Kaidu (Isengul volost) of the Saribagish tribe. Choko was exiled twice. The first time was to the Nizhnii-Ili volost, Vernyi uezd in 1896, and the second to Osh uezd, Ferghana oblast in 1902. The second manap was Kasïmbek Bakotay (Choro volost) of the Sayak tribe, who was exiled to the Ferghana oblast in 1902.

41 However, the exile policy was not as effective as hoped. In fact, after being exiled to Vernyi uezd for extortion and collecting illegal tax, Choko Kaidu, working through the Isengul volost administrator and others, collected 700 rubles' worth of taxes from the local population. ${ }^{61}$ Furthermore, when he returned to his home in the Isengul volost after completing his sentence, he wasted no time in rebuilding the "obstacle," by making his son the volost administrator and filling the official positions of the volost with members of his own faction. This allowed choko to once again collect taxes from the common people. ${ }^{62}$ Thus, while the exile of the manaps appeared to be a radical policy, it was actually a measure taken due to the "weakness" of Russian military authority.

\section{Manaps under the development of the resettlement policy}

The early years of the $20^{\text {th }}$ century marked a major turning point in Russian rule in Central Asia. One of the key policies during this period was the resettlement policy ( zemleustroistvo). In fact, the Stolypin government introduced the program in order to send surplus population in the central part of the empire to the peripheries, as immigrants. ${ }^{63}$ Under this policy, Central Asia and in particular the Semirech'e oblast was to be a major destination for Russian peasant migrants. To advance this policy, it was essential to 
expropriate land from local nomads, which naturally necessitated close negotiations with them. How the Russian military authorities positioned manaps in the context of this situation reveals much about their relationship with them, and is the focus of this chapter.

\section{The Resettlement administration as a new supporter of the anti- manap struggle}

43 In 1905, in order to execute the resettlement policy in Semirech'e oblast, the branch office of the Resettlement administration (Pereselencheskoe upravlenie) was set up and placed under the jurisdiction of the Main Administration of Land Management and Agriculture (Glavnoe upravlenie zemleustroistva i zemledeliia). The main priority of the body was securing land for Russian settlers by appropriating it from the nomads. However, it also sought to use the program as a lever for advancing social reform among the nomads of the area. The first head of the Resettlement administration in Semirech'e, O. Shkapskii, saw the society of Kyrgyz nomads as one in the process of a class struggle between feudal lords (manaps) and the common people..$^{64}$ This idea not only paralleled the relationship between Russian landlords and peasants, but also took the prevailing idea about manaps and the common people and adapted it into the context of the Narodonik movement. ${ }^{65}$ Within this context, officials of the Resettlement administration believed that it would be possible to emancipate the common people from the "yoke of manaps" by organizing them into settlement villages independent from manaps. The belief was that Russian migrants would be able to settle in the surplus of agricultural areas secured as a result of the resettlement of the Kyrgyz common people. ${ }^{66}$ By encouraging a transition from nomadic to sedentary life, the Resettlement Administration was waging an anti-manap struggle. Administration officials approached Kyrgyz nomads to encourage them to also make this transition, which they did in part by using the factional infighting over volost elections: the Resettlement Administration would approach faction leaders who had lost volost elections and suggest they petition the Russian military authorities for settlement ( perekhod $v$ osedlost') by dividing up the existing volost. Faction leaders believed that they could not only take power as an administrator of the newly established sedentary volost, but also secure land as soon as possible in advance of land expropriation.

As for manaps who held sway in the volosts, they responded to the tactic by using the people's courts, which were under their influence, to put pressure on those Kyrgyz who were pro-settlement. An author called Sh.V. described this situation in an article entitled "On the Kyrgyz," which appeared in 1911 in the Tatar journal shūrā:

When the common people (fuqara) complain to the [Russian] authorities about manaps, manaps of the volost use a variety of means within their grasp to cheat the officials. [Manaps] then [...] accuse the common people in the people's court, saying things like "he is not paying his taxes" or "I have reported this man because he is a thief". [...] The judges of the people's court (bis) are comprised of men selected from the close acquaintances and supporters of manaps. Manaps compel the bis to help them seize livestock from the Kyrgyz who resisted them. All of these actions are carried out within the law. ${ }^{67}$

According to a petition sent to the governor-general of Turkestan by Kyrgyz representatives advocating settlement in the Sukuluk volost, Pishpek uezd, all of the judges of the people's court in the volost at the time were selected from the followers of Cholpankul, the manap who controlled the volost. As a matter of fact, Cholpankul had 
brought a number of complaints to the people's court against these Kyrgyz with the aim of forcing them to abandon their plans to become sedentary. ${ }^{68}$

\section{Russian military authorities still relying on manaps}

However, the response to this situation from Russian military authorities, including the oblast government of Semirech'e was generally half-hearted. In 1907, the individuals concerned held a meeting in Vernyi regarding the resettlement issues. In the meeting, the Resettlement administration characterised the settlement movement as an attempt to seek "emancipation from manaps," and emphasised the historical significance of such a goal. In contrast, the oblast government described it as a movement seeking the "emancipation from their burdens" in the context of factional infighting over volost elections. ${ }^{69}$ In fact, despite the order from the Turkestan governor-general to protect the pro-settlement Kyrgyz from oppression via the people's courts, the oblast government did not take any specific countermeasures and instead delegated the entire matter to the lower local military authorities.

However, not only were local military authorities indifferent to the settlement movement, they actually aided and abetted manaps. For example, Shkapskii gives the following statement regarding the response of the uezd commander to his task of protection:

The pro-settlement Kirgiz [i.e. Kyrgyz] are concerned that if they prepare a list of advocates for settlements, the uezd commander will gain knowledge of these names and pass it to manaps, and then the advocates will be [accused in the people's court and] found guilty. [...] In the Kirgiz [i.e. Kyrgyz] view, even the uezd commander is an informant of manaps. ${ }^{70}$

Such an attitude was even more pronounced in the police force of the district (Uchastkovyi pristav), an institution set up under the uezd's jurisdiction in $1902 .{ }^{71}$ While it was responsible for surveilling the local population, the police preferred to maintain order by forging a cooperative relationship with manaps rather than engaging in the struggle against them. Given such a cooperative relationship, the police officers were more intent on suppressing the settlement movement than protecting it. A settlement movement leader in the Sukuluk volost wrote of the police officer in the Belovodskii district, G. Fovitskii, that he was "a complete enemy of settlement":

Fovitskii is under the thumb of the manaps who oppose settlement. [...] He is in debt to Cholpankul and other manaps in the district. He [...] has time and time again demanded that requests for settlement be withdrawn. ${ }^{72}$

Moreover, when it was decided at the assembly of the Sukuluk volost in 1908 to exile the leading advocates of settlement, the plan was supported not only by the police officer of the district, but also by the uezd commander. ${ }^{73}$

There was even an example of the reliance on manaps in the Tomak district, evidenced by the words of D. Uraevskii, who had worked at the district:

[...] Kutukov, the police officer of the Tokmak district and his predecessor stuck to a policy of maintaining a good relation with the members of Shabdan's family. The reason for this is that the Shabdan family considerably eased the burden of controlling the district. [...] It was not possible for the police officer to solve various problems that occurred in the district without the support of manaps." ${ }^{\prime 4}$

51 Even after Shabdan's death, Kutukov sought to maintain the influence of his family. In fact, when the forces opposed to the Shabdan's family attempted to use the settlement 
policy to divide the volost, the district police officer tried to prevent them from doing so. According to a petition lodged by Kyrgyz seeking settlement in the volost, the police officer visited and pressured them to abandon their plan with the following argument:

There is no benefit from becoming farmers (krest'iane). The farming life and the customary law (adat) do not go together. [If you were to become farmers] you will drink wine, eat pork [...]. Therefore, you should not abandon this nomadic life. ${ }^{75}$

Looking particularly at the At-Bash district (where the anti-manap struggle had raged) offers further insight into the relationship between the administration and manaps. In 1911, the pro-settlement Kyrgyz in the Sayak volost complained to an official of the Resettlement administration, Mazurenko, about the "oppression from manaps" including the levying of taxes. ${ }^{76}$ The commander of the At-Bash district, who had been entrusted by the oblast government to deal with the matter, had the following to say:

The collection of taxes from the common people by manaps is a time honoured custom, and inasmuch as manaps do not work in official posts, they are beyond the purview of the Russian courts. The struggle against this custom, which wreaks havoc in the lives of the common people, must be waged through administrative channels, that is to say, through the people's courts. ${ }^{77}$

Based on this belief, he strongly urged against the involvement of Resettlement administration officials in public administration and revealed that "with the solicitation of Mazurenko, his secretary wrote the petition." ${ }^{78}$ In other words, the commander of the At-Bash district was more concerned about the presence of the officials of the Resettlement administration than he was about the anti-manap struggle. Thus, during the campaign to promote the resettlement policy, instead of cooperating to advance the struggle against the manaps, local military authorities not only turned a blind eye to their activities, but also actually utilised manaps to maintain order.

The importance of manaps as mediators would come to be recognised not only among Russian military authorities at the local level, but also among the upper echelons. Evidence for this exists in a matter that concerned the allocation of land to the manap Shabdan. In 1903, Shabdan had demanded that the governor-general of Turkestan allocate him 400 desiatina worth of land as befitting a Lieutenant Colonel. While the oblast government of Semirech'e agreed with the request, the Resettlement administration strongly opposed. As a report by a Resettlement administration official describes:

Manaps, and in particular, Shabdan of the Saribaghïsh tribe, and Cholpankul of the Solto tribe, both of whom hold the fate of Kyrgyz in their hands, are completely opposed to the settlement campaign, and they are using every available means to fight against it. ${ }^{79}$

For this reason, the matter was shelved for a few years.

It resurfaced, however, and began to rapidly develop as the resettlement policy became a more pressing issue. With the tough initiatives launched by the Stolypin government in 1909 , the restrictions on Russian settlement into Semirech'e oblast were formally lifted. ${ }^{80}$ At the same time the regulations governing the appropriation of land, including the provisions concerning nomads' transition to sedentary life (Instruktsii o poriadke opredeleniia gosudarstvennogo zemel'nogo fonda $v$ oblastiakh Akmolinskoi, Semipalatinskoi, Turgaiskoi $i$ Ural'skoi dlia pereseleniia, a ravnykh gosudarstvennykh nadovnostei), were approved by the Council of Ministers (Sovet Ministrov). ${ }^{81}$ In this situation, the governorgeneral of Turkestan, A.V. Samsonov, believing that Shabdan would have to be placated in order to achieve a full-scale land appropriation, argued strongly in favour of allocating 
land to him. However, Samsonov failed to reach an agreement with the Resettlement administration, which continued to voice its opposition to the allocation proposal, ${ }^{82}$ and the matter was ultimately entrusted to the Council of Ministers. ${ }^{83}$ This prompted Samsonov to make a tour of Semirech'e oblast and arrange an audience with Shabdan. Following the meeting, Samsonov began corresponding with A. Krivoshein, the director of the Main Administration of Land Management and Agriculture:

The Kirgiz [i.e. Kyrgyz] are gullible, and tend to be shallow, carefree, and naturally childlike. Because they lead primitive lives, when they are faced with the conditions of a cultured way of life, which is yet unknown to them, and the new demands arise from it, they cannot avoid turning to "manaps" in particular for support and protection. Manaps are an ancient institution from the past patriarchal way of life, but among the unenlightened Kirgiz masses who inhabit the Steppe, manaps reign supreme, and continue to wield a great deal of power. [...] For this reason, what the Kirgiz perceive with regard to all the policies of Russia reflect nothing else but how manaps interpret matters. [...] This fact must be taken into consideration when tackling the extremely important issue, namely the issue of encouraging the 800 thousand Kirgiz living in Semirech'e to change their way of life. ${ }^{84}$

Thus, while Samsonov considered manaps to be an "ancient institution," he strongly emphasised their role as mediators. He went on to say that, "Shabdan definitely understands that the shift to a sedentary life is unavoidable in the future and that it can bring benefits. He is explaining this to the common people." ${ }^{15}$ Samsonov also emphasized the importance of Shabdan's role, saying: "Under conditions where there is no police force whatsoever, Shabdan is an extremely desirable opponent in the struggle against the agitation activities of Kazan-Tatar." ${ }^{86}$ In other words, it can be said that setting aside the anti-manap struggle, he repositioned Shabdan in the context of the struggle against the so -called "Pan-Islamic" movement. Thus, Samsonov argued that in order to smoothly advance the resettlement policy, it was absolutely essential that Shabdan-as the key representative of manaps-be allocated the land he desired. Reflecting on Samsonov's "persistent and firm demands", the Council of Ministers, in October 1910, gave their approval to a special allocation of land whereby Shabdan would be given the right to use 400 desiatina for life.$^{87}$ Having thus carried through the resettlement policy, Russian military authorities could by no means ignore the influence of manaps, and Shabdan in particular.

It was outlined in this chapter that, rather than using the resettlement policy as a lever to intervene in the society of Kyrgyz nomads and undermine the power of the manaps, Russian military authorities continued to rely on them as mediators. In other words, as the resettlement policy became a pressing issue, the "close" relationship between Russian military authorities and manaps become distinct. Meanwhile, there remained a large gulf between Russian military authorities and the common people (narod). As pointed out in the article "On the Kyrgyz," even if the common people petitioned the Russian authorities, their statements would not be believed. ${ }^{88}$ In fact, leading advocate of settlement in the Saribagish volost Alike Alimbek made the following complaint in a letter addressed to the governor-general of Turkestan:

Manaps led by the sons of the late Shabdan oppose settlement. [...] By exploiting the goodwill of the [Russian military] administration towards Shabdan, they are hedging us in with an unbreakable net. They bring cases to court in such a way that we are regarded as tricksters, and that only their words are believed. ${ }^{89}$ 


\section{Conclusion} maintaining passive stability, the manaps could suddenly and easily change from collaborator to resister due to their incomplete integration into the Russian system of authority. After Shabdan's death, Russian military authorities did not allow his descendants to inherit either his title of Lieutenant Colonel or his specially allotted land ${ }^{92}$ and thus prevented them from becoming hereditary elites. Shabdan's heirs' dissatisfaction with this measure reached a breaking point in 1916 and a large-scale revolt broke out in Russian Central Asia that same year. The revolt included the participation of the Kyrgyz nomads of southern Semirech'e, among others. The catalyst for this revolt was a sudden decree ordering compulsory conscription to military service, a move aimed to address the shortage of Russian soldiers fighting in World War I. This revolt helped encourage the collapse of the Russian Empire. ${ }^{93}$ As can be seen from the quotation at the beginning of this article, A.N. Kuropatkin, who was appointed as a governor-general of Turkestan in order to settle the disorder, had to witness the shocking 
and ironical spectacle: the sons of a former collaborator, Shabdan, whom Kuropatkin himself had supported, now rising against the Russian Empire.

\section{NOTES}

1. A.V. Piaskovskii, ed., Vosstanie 1916 goda v Srednei Azii i Kazakhstane : sbornik dokumentov [The uprising of 1916 in Central Asia and Kazakhstan: a collection of documents] (M., 1960), 345-346. According to their autonyms they called themselves Qïrghïz. However, in this article I use Kyrgyz in accordance with customary practice. In official documents dated to 1925, Kyrgyz and Kazakhs were called generically as "kirgiz." Occasionally, while Kazakhs were called "kirgiz-kaysak" or "kirgiz-kazak," Kyrgyz were called "dikii kirgiz [wild Kirgiz]," "kamennyi kirgiz (mountain Kirgiz)," “dikokamennnyi kirgiz" or "kara-kirgiz [black Kirgiz]".

2. Shiokawa Nobuaki, Minzoku to Neishon : Nashonarizumu to iu Nanmon [Ethnicity and nation : hardship called nationalism] (Tokyo : Iwanami Shoten, 2008), 58.

3. Tomohiko Uyama, "A Particularist Empire: The Russian Policies of Christianization and Military Conscription in Central Asia," in Tomohiko Uyama, ed., Empire, Islam, and Politics in Central Eurasia (Slavic Eurasian Studies, 14) (Sapporo: Slavic Research Center, Hokkaido University, 2007), 59.

4. Ronald Robinson, "Non-European Foundations of European Imperialism : Sketch for a Theory of Collaboration," in Roger Owen \& Bob Sutcliffe, eds., Studies in the Theory of Imperialism (London : Longman, 1972), 117-142.

5. A.V. Remnev, "Tatary v Kazakhskoi stepi : soratniki i soperniki rossiiskoi imperii [The Tatars in the Kazakh Steppe: comrades-in-arms and rivals of the Russian Empire]," Vestnik evrazii, 4 (2006) : 5-31.

6. Alexander Morrison, Russian Rule in Samarkand : 1868-1910. A Comparison with British India (Oxford : Oxford University Press, 2008).

7. Virginia Martin, "Kazakh Chinggisids, Land and Political Power in the Nineteenth Century : A Case Study of Syrymbet," Central Asian Survey, 29, 1 (2010) : 79-102; Gulmira Sultangalieva, "Kazakhskoe chinovnichestvo Orenburgskogo vedomstva: formirovanie i napravlenie deiatel 'nosti (XIX) [Kazakh officials of the Orenburg administration: formation and direction of activities (XIX)]," Acta Slavica Iaponica, 27 (2009) : 77-101; Zh. Dzhampeisova, Kazakhskoe obshchestvo i pravo v poreformennoi stepi [Kazakh community and law after the Great Reform] (Astana, 2006).

8. According to Kyrgyz ethnography, the origin of this title is said to be the name of a leader of the Saribagïs tribe in the 17th century. In the beginning of the $19^{\text {th }}$ century, the use of manap as a title of tribal chieftain was spread among the neighbouring tribes including Solto, Bugu and Sayak. S.M. Abramzon, Kirgizy i ikh ètnogeneticheskie i istoriko-kul'turnye sviazi [The Kyrgyz and their ethnogenetic and historical-cultural relationships] (Bishkek, 1990), 168-169.

9. Daniel Prior, The Sabdan Baatır Codex : Epic and the Writing of Northern Kirghiz History (Leiden·Boston : Brill, 2012).

10. Tetsu Akiyama, "Roshia Tōchi-ka ni okeru Kuruguzu Shuryō-sō no Ken'i ni tsuite : Yūboku Sekai to Isuramu Sekai no aida de [On the authority of the Kyrgyz chieftain class under the Russian rule : between the nomadic and Islamic worlds]," Tōyōshi Kenkyū, 71, 3 (2012) : 29-57. 
11. Tetsu Akiyama, "Nomads Negotiating the Establishment of Russian Central Asia : Focusing on the Tribal Chieftains of Kyrgyz Nomads," Memoirs of the Research Department of the Toyo Bunko, 71 (2014) : 141-160.

12. Daniel G. Prior, "High Rank and Power among the Northern Kirghiz: Terms and Their Problems, 1845-1864," in Paolo Sartori, ed., Explorations in the Social History of Modern Central Asia (19th- Early 20th Century) (Leiden - Boston : Brill, 2013), 137-179.

13. M.F. Gavrilov, "Manap," in B.B. Karp, N.E. Suslov, eds., Sovremennyi aul Srednei Azii (sotsial 'no-èkonomicheskii ocherk) [Contemporary aul (village of nomads) in Central Asia (Socioeconomic Outline)] (Tashkent, 1927), 210.

14. P.G. Geiss, Pre-Tsarist and Tsarist Central Asia : Communal Commitment and Political Order in Change (London-New York: Routledge Curzon, 2003), 172-221; D.B. Saparaliev, "Sistema upravleniia Kyrgyzov v sostave Rossiiskoi imperii (1855-1917gg.) [Administration system of the Kyrgyz as part of the Russian Empire]," Koomduk ilimder jurnalï (Kïrgïz-Türk « Manas» universiteti), 12 (2004) : 47-59.

15. Daniel Brower, Turkestan and the Fate of the Russian Empire (London-New York: Routledge Curzon, 2003), 30.

16. Proekt polozheniia ob upravlenii Semirechenskoi i Syr-Dar'inskoi oblastei [Draft statute on administration of Semirech'e and Syr-Dar'ya oblasts] (SPb. : 1867), 129.

17. RGIA (Rossiiskii gosudarstvennyi istoricheskii arkhiv), f. 1291, Zemskii otdel MVD [Zemstvo (Regional) Department of the Ministry of Internal Affairs], op. 82, d. 6-1891, Ob"iasnitel'naia zapiska $\mathrm{k}$ proektu polozheniia ob upravlenii oblastei Akmolinskoi, Semipalatinskoi, Semirechenskoi, Ural'skoi i Kazalinskoi [Explanatory note on the draft statute on administration of Akmolinsk, Semipalatinsk, Semirech'e, Ural'sk and Kazalinsk oblasts], 1. 5.

18. Akiyama, "Nomads Negotiating the Establishment of Russian Central Asia," 151.

19. Ibid., 155.

20. TsGA RK (Tsentral'nyi gosudarstvennyi arkhiv respubliki Kazakhstan), f. 44, Semirechenskoe oblastnoe pravlenie [Semirech'e oblast government], op.1, d. 30244, Delo po prosheniiu kirgiza Tokmakskogo uezda, Sarybagyshevskoi volosti, Serdybeka Urkunbaeva, zhaluiushchagosia na kirgiza Shabdana Dzhantaeva [File on petition of a Kyrgyz of Tokmak uezd of Sarybagysh volost Serdybek Urkunbaev complaining of a Kyrgyz Shabdan Dzhantaev], 1. 12.

21. TsGA RK, f. 44, op. 1, d.1217, Delo o sostavlenii proekta polozheniia dlia Semipalatinskoi, Akmolinskoi i Semirechenskoi oblastei [File on drawing up a draft statute for Semipalatinsk, Akmolinsk and Semirech'e oblasts], 1. 235.

22. TsGA RK, f. 44, op. 1, d. 28959, Delo o vvedenii stepnogo polozheniia v novoobrazovannykh oblastiakh i ob organizatsii administrativnogo upravleniia $\mathrm{v}$ kochevom naselenii [File on introduction of the Steppe statute in newly formed oblasts and on organization of administration among nomadic populations], 1.18-20.

23. TsGA RUz (Tsentral'nyi gosudarstvennyi arkhiv respubliki Uzbekistan), f. I-1, Kantseliariia Turkestanskogo General Gubernatora [Secretariat of Turkestan governor-general], op. 20, d.3801, Vypiska iz zhurnal'nogo postanovleniia Obshchego Prisutstviia Semirechenskogo oblastnogo pravleniia 5 sentiabria 1870 goda o neudovletvoritel'nom polozhenii narodnogo upravleniia, o prichinakh togo i o merakh $\mathrm{k}$ ustraneniiu sushchestvuiushchikh nedostatkakh [Record extract of a journal act of the common office of Semirech'e oblast administration as of September $5^{\text {th }}$, of the year 1870 , on the unsatisfactory situation of the public administration, and its reasons, as well as on measures for elimination of existing problems], 1. 5.

24. TsGA RK, f. 44, op.1, d. 31755, Delo po raportu Tokmakskogo uezdnogo nachal'nika o bezporiadkakh proizvodimykh kirgizom Dikanom Roskul'bekovym [File on the report of the Tokmak uezd commander on turmoil caused by a Kyrgyz Dykan Roskul'bekov], 1. 5ob.

25. M.G. Masevich ed., Materialy po istorii politicheskogo stroia Kazakhstana [Materials on history of political order of Kazakhstan ], 1 (Alma-Ata : 1960), 299. 
26. TsGA RUz, f. I-1, op. 20, d.3806, Delo po povodu khodataistva Semirechenskogo voennogo gubernatora o peresmotre dela kirgiza Tatibeka Tatygulova s kirgizom Kurman Khozheiu [File on petition of Semirech'e military governor on revision of the case of a Kyrgyz Tatybek Tatygulov with a Kyrgyz Kurman Khozha], 1. 5ob.-6.

27. TsGA RUz, f. I-1, op. 20, d. 3806, 1. 41ob.

28. TsGA RK, f. 44, op. 1 , d. 31638 , Delo ob otpravlenii v Moskvu dlia prisutstvovanii na Koronovanii Ikh Imperatorskikh Velichestv deputatov ot Semirechenskoi oblasti [File on sending deputies of Semirech'e oblast to Moscow to attend the coronation of their imperial majesties], 1. 53-53ob.

29. Semeinyi arkhiv potomkov Shabdana baatyra [Family archive of descendants of Shabdan Baatyr]. For using this family archive I am grateful to Janyl Abdyldabek Kyzy, Shabdan's great-granddaughter.

30. "O zapreshchenii isprashivat' voinskie nagrady i v osobennosti voennye chiny Bashkiram, Kirgizam, Kalmykam i drugim inorodcheskim plemenam [On prohibition of asking for military awards, especially military ranks, for the Bashkirs, Kazakhs, Kyrgyz, Kalmyks and other alien tribes]," in Polnoe sobranie zakonov Rossiiskoi imperii, dopolnenie k XLII-mu tomu vtorogo sobraniia [Complete collection of laws of the Russian Empire, appendix to volume XLII of the second collection] (2 Aprelia, 1867), 8.

31. TsGA RK, f. 44, op. 1, d. 42221, Delo o proizvodstve s"emki zemel' pod osedlye poseleniia i obrochnye stat'i v Pishpekskom uezde [File on land survey intended for settled colonies and Obrok rent in Pishpek uezd], 1. 321.

32. According to the biography of Shabdan (written by his son Kamal Shabdanov), A.N. Kuropatkin, who had taken part in the conquest of Central Asia and was also invited to the coronation, eagerly supported the measure. See : Rukopisnyi Fond Natsional'noi Akademii Nauk Kyrgyzskoi Respubliki, No. 158, Kamal Shabdanov, Atabïz Shabdan baatïr tuuralu jazïlgan tarikhi [A life history of our father Shabdan Batyr], Rybach'e , 1947, 1. 18.

33. P. Semënov, "Kirgizy," in Geografichesko-statisticheskii slovar' Rossiiskoi imperii [Geography-Statistics Dictionary of the Russian Empire], 2 (SPb. : 1865), 596.

34. See, for example: Ch.Ch. Valikhanov, "Zapiska o Kirgizakh [Notes on the Kyrgyz]," in Sobranie sochinenii v piati tomakh [Collected works in five volumes], 2 (Alma-Ata : 1985), 38, 39 ; A.K. Geins, "Dnevnik 1866 goda. Pyteshestvie v Turkestan [Diary of the year 1866. Journey to Turkestan]", in Sobranie literaturnykh trudov A.K.Geinsa [Collection of literary works of A. K. Geins], 1 (SPb. : 1898), 419 ; M. Veniukov, "Ocherki Zailiiskogo i Prichuiskoi doliny [Essays of Zailiisky and Prichuisky valley]", in Puteshestvie po russkoi Azii i zapiski o nikh [Journey across Russian Asia and commentary on the said journey] (SPb. : 1868), 158-159 ; N.A. Maev, Putevoditel' ot S.-Peterburga do Tashkenta [A guide from St. Petersburg to Tashkent] (SPb. : 1870), 10-11.

35. M.K. Baskhanov, Russkie voennye vostokovedy do 1917 g. : Bibliograficheskii slovar' [Russian military orientalists before 1917. Bibliographic dictionary] (M.: Vostochnaia literatura RAN, 2005), 86.

36. G. Zagriazhskii, "Iuridicheskii obychai Kirgizov o razlichnykh rodakh sostoianii i o pravakh, im prisvoennykh [Legal practice of the Kyrgyz on status of different clans and on rights they were given]", in N.A. Maev, ed., Materialy dlia statistiki Turkestanskogo kraia [Materials for statistics of Turkestan Krai], 4 (SPb. : 1876), 151-152.

37. "Svedeniia o dikokamennykh Kirgizakh [Information on dikokamennyi (wild-mountain) Kyrgyz]", Zapiski imperatorskogo russkogo geograficheskogo obshchestva, 5 (SPb. : 1851) : 140 ; Valikhanov, "Zapiska o Kirgizakh", 40-41.

38. L. Kostenko, Sredniaia Aziia i vodvorenie v nei russkoi grazhdanstvennosti [Central Asia and implementation there of Russian civic values] (SPb. : 1871), 47 ; A. Khoroshkhin, "Baituk-batyr (rasskaz iz kara-kirgizskoi zhizni, 1867 goda) [Baituk-batyr (A story from Kara-Kyrgyz life)]", 
Turkestanskie vedomosti, 43 (1872) ; E.Smirnov, Syr-Dar'inskaia oblast' : Opisanie po ofitsial'nym dannym [Syr-Dar'ya oblast : Description based on official data] (SPb. : 1887), 55.

39. RGIA, f. 1276, Sovet ministrov [The Council of Ministers], op. 6, d. 712, Ob otvode voiskovomu starshine militsii Dzhantaevu zemel'nogo uchastka v Semirechenskoi oblasti [On allotting a plot of land in Semirech'e oblast to Militia Lieutenant Colonel Dzhantaev], 1. 11ob.

40. Materialy po kazakhskomu obychnomu pravu [Materials on customary law of Kazakh] (Almaty : Zhetí Zharghï, 1996), 52.

41. For a further discussion of petitions submitted by local population of Russian Central Asia, see Paolo Sartori, "Constructing Colonial Legality in Russian Central Asia : on Guardianship," Comparative Studies in Society and History, 56, 2 (2014) : 419-447. In this article, he argues that in allowing the local population to file their grievances with military bureaucracy, the Russians effectively pushed Central Asians to reify colonial notions of justice, and thereby distance themselves from the tradition of Islamic legal practices. As for the comparative study of petitions submitted by both sedentary and nomadic population of Central Asia, there is room for further investigation.

42. TsGA RK, f. 44, op. 1, d. 35769, Sarybagishevskoi volosti kirgizy prosiat izbavit' ot nasilii i zloupatreblenii manapov Dzhantaevykh [The Kyrgyz of Sarybagish volost ask to free themselves Violence and abuse by the Dzhantaevs manaps], 1. 35-35ob.

43. TsGA RK, f. 44, op.1, d.6619, Dzhantaev Shabdan, Kuptuanov Bazhe i drugie manapy po zhalobam Kirgizov Pishpekskogo Uezda na deistvie ètikh lits [Dzhantaev Shabdan, Kuptuanov Bazhe and other manaps as mentioned in complaints of the Kyrgyz of Pishpek uezd about actions of these individuals], 1. 10.

44. TsGA RK, f. 44, op. 1, d. 6619, 1. 14ob.-35ob.

45. TsGA RK, f. 44, op. 1, d. 6619, 1. 14ob.-35ob.

46. TsGA RK, f. 44, op. 1, d. 695, Khodataistvo ob uvelichenii pensii Voiskovomu Starshine militsii Shabdanu Dzhantaevu Sarybagishevskoi volosti Pishpekskogo uezda [Petition on increase of pension for militia lieutenant colonel Shabdan Dzhantaev of Sarybaghish volost of Pishpek uezd], 1. $60 \mathrm{ob} .-7$.

47. TsGA RK, f.64, Kantseliariia Stepnogo general gubernatora [Secretariat of the Steppe governor-general], op. 1, d. 516, Raport nachal'nika Tokmakskogo uezda Semirechenskoi oblasti o razdelenii Kul'chugagel'skoi volosti na dve [Report of the commander of Tokmak uezd of Semirech'e oblast on the dividing in two of Kul'chugagel' volost], 1. $20 \mathrm{ob}$.

48. TsGA RK, f. 44, op. 1, d. 1890, Delo o naznachenii Mulatalina perevodchikom Pishpekskogo uezdnogo upravleniia [File on appointment of Mulatalin, an interpretor of Pishpek uezd administration], 1. 15.

49. For more on the school project, see: Obiya Chika, "Ostoroūmofu no mita Roshia ryō Torukisutan [Russian Turkestan, as viewed by N.P. Ostroumov]”, Roshiashi Kenkyū, 76 (2005) : 21-22.

50. Karakirgiz, “Otkrytie shkol [Establishment of schools]”, Dālā vilāyatīning gāzītī, 20 (1896).

51. Karakirgiz, "Korrespondentsiia iz Pishpekskogo uezda", Dālā vilāyatīning gāzītī, 38 (1897).

52. A.A. Dobrovol'skii ed., Svod zakonov Rossiiskoi imperii dopolnennyi po prodolzheniiam 1906, 1908, 1909 i 1910 gg. i pozdneishim uzakoneniiam 1911 i 1912 gg. [Code of laws of the Russian Empire completed according to extensions of the years 1906, 1908, 1909 and 1910 and later statutes of the years 1911 and 1912] (SPb. : Zakonovedenie, 1913), 1170-1171.

53. TsGA RUz, f. I-1, op.13, d.587, Delo po prosheniiam i zhalobam tuzemtsev po delam, kasaiushchimsia vyborov $\mathrm{v}$ Semirechenskoi oblasti [File on petitions and complaints of the indigenous population on cases related to elections in Semirech'e oblast], l.106.

54. TsGA RK, f. 44, op. 1, d. 1745, Delo po voprosu o preobrazovaniia Atbashinskogo uchastka v samostoiatel'nyi uezd [File on the case of reorganization of At-Bash district to an independent uezd], 1.5. 
55. Belek Soltonoev, Kïrgïz tarïkhï [A history of Kyrgyz] (Bishkek : Arkhi, 2003), 296.

56. TsGA RK, f. 44, op. 1, d.7768, Bondarev pisar' Saiakovskoi volosti Przheval'skogo uezda Semirechenskoi oblasti [Bondarev, the clerk of Saiak volost of Przhevalsk uezd of Semirech'e oblast], 1.24ob. ; TsGA RK, f. 44, op. 1, d. 7838, Delo po raportu Przheval'skogo uezdnogo nachal 'nika, pri kotorom predstavleno doznanie po obvineniiu Chorinskogo volostnogo pisaria Nikolaia Chukreeva za vziatochnichestvo [File on the report of Przhevalsk uezd commander in whose presence an interrogation was held of Chorinsk volost clerk Nikolai Chukreev charging him with bribery], 1. 1.

57. TsGA RK, f. 44, op. 1, d. 1745, 1. 5.

58. The 15th clause of the "Statute for the administration of the Turkestan region" stipulated that consent of the Ministry of Internal Affairs was required in the case of exile. Dobrovol'skii, ed., Svod zakonov Rossiiskoi imperii,1128.

59. TsGA RUz, f. I-1, op. 4, d. 659, Delo o vysylke kirgiz Przheval'skogo uezda Choki Koidueva i Kasymbeka Bagotaeva v Stepnoi krai na piat' let [Records on exile of the Kyrgyz of Przhevalsk uezd Choki Koiduev and Kasymbek Bagotaev to Steppe krai for five years], 1. 6.

60. TsGA RUz, f. I-1, op. 4, d. 659, 1. 7, 31.

61. TsGA RUz, f. I-1, op. 4, d. 659, 1. 2.

62. TsGA RUz, f. I-1, op. 4, d. 659, 1. 2.

63. Katsunori Nishiyama, Roshia Kakumei to Tōhō Henkyō Chiiki : "Teikoku" Chitsujo kara no Jiritsu o motomete [The Russian Revolution and the Eastern peripheries: in search of the independence from the "imperial" order] (Sapporo : Hokkaido daigaku shuppankai, 2002), 129.

64. O.A. Shkapskii, "Kirgizy-krest'iane (iz zhizni Semirech'ia) [Kyrgyz farmers (From Semirech'e life)]", Izvestiia imperatorskogo russkogo geograficheskogo obshchestva, 41 (1905) : 765-778.

65. Among the officials of the Resettlement administration, there were not a few who had a background in the Narodonik movement. See : Nishiyama, Roshia kakumei to Tōhō Henkyō Chiiki, 105 ; G.B. Khabizhanova, Ė.zh. Valikhanov, A.L. Krivkov, Russkaia demokraticheskaia intelligentsiia $\mathrm{v}$ Kazakhstane (vtoraia polovina XIX-nachalo XXv.) [Russian democratic intellectuals in Kazakhstan (the second half of 19th - the beginning of 20th century], (M. : Russkaia kniga, 2003).

66. V. Voronkov, Po voprosu o pozemel'nom ustroistve tuzemnogo kirgizskogo naseleniia v Semirechenskoi oblasti [On the problem of land organization of indigenous Kyrgyz inhabitants of Semirech'e oblast] (Vernyi : 1908) ; V. Vasil'ev, Semirechenskaia oblast' kak koloniia i rol' v nei Chuiskoi doliny [Semirech'e oblast as a colony and the role of Chui valley] (Pg. : 1915).

67. Sh. V., "Qirğìzlar țūğrūsinda [On the Kyrgyz]," Shūrā , 4 (1911) : 102.

68. TsGA RK, f. 44, op. 1, d. 25996, Perepiska po prosheniiu doverennykh ot 725 kibitkovladel'tsev Sukulukskoi i drugikh volostei [Correspondence on petition of the deputies of 725 owners of kibitka (households) of Sukuluk and other volosts], 1. 257-257ob.

69. TsGA RK, f. 19, Zaveduiushchii pereselencheskim delom v Semirechenskom raione Glavnogo upravleniia zemleustroistva i zemledeliia [Curator of resettlement in Semirech'e district of the main administration of land management and agriculture], op.1, d.56, Delo o revizii Semirechenskogo pereselencheskogo raiona pomoshnikom Turkestanskogo general-gubernatora Kondratovichem [File on inspection of Semirech'e resettlement district by the assistant to the Turkestan governor-general Kondratovich], 1.166ob.-167ob.

70. O.A. Shkapskii, "Pereselentsy $\mathrm{i}$ agrarnyi vopros $\mathrm{v}$ Semirechenskoi oblasti [Migrants and agrarian issues in Semirech'e oblast]," Voprosy kolonizatsii, 1 (1907) : 46.

71. Dobrovol'skii, ed., Svod zakonov Rossiiskoi imperii,1171. In the Pishpek uezd two districts were established: one was the Belovod district near uezd's capital Pishpek, and another was the Tokmak district. See Map 2. 
72. TsGA RK, f.44, op. 1, d. 10801, Delo o perepiskoi po vydvoreniiu kirgiza Sukulukskoi volosti Dzhantaia Kenesarina [File on correspondence on the exile of a Kyrgyz of Sukuluk volost Dzhantai Kenesarin], 1. 27-27ob.

73. TsGA RK, f. 44, op. 1, d. 10801, 1. 2, 42.

74. TsGA RK, f. 44, op. 1, d. 20951, Delo o tesnoi druzhbe Shtabs-Kapitana Kutukova s pokoinym Shabdanom Dzhantaevym [File on intimate friendship of staff captain Kutukov with the late Shabdan Dzhantaev], 1. 17.

75. TsGA RK, f. 19, op. 1, d. 1364, Delo po prosheniiu kirgiz Sarybagishevskoi volosti o zhelanii ikh pereiti $\mathrm{v}$ osedlost' [File on petition of the Kyrgyz of Sarybagish volost on their intention to settle], 1.98 .

76. TsGA RK, f. 44, op.1, d.21155, Delo po prosheniiu kirgiz Saiakovskoi volosti Mambetaly Abdrasulova o nezakonnykh deistviiakh manapov [File on petition of the Kyrgyz of Saiak volost Mambetaly Abdrasulov on illegal actions of manaps], 1. 4-5.

77. TsGA RK, f. 44, op. 1, d. 21155, 1. 6 ob.

78. TsGA RK, f. 44, op. 1, d. 21155, 1. 2ob.-3ob.

79. TsGA RK, f. 44, op. 1, d. 25996, 1. 102ob.

80. Nishiyama, Roshia kakumei to Tōhō Henkyō Chiiki, 130.

81. Osobyi zhurnal soveta ministrov [Special journal of the council of ministers] (SPb: 25 Noiabria, 1909), 6-7.

82. TsGA RUz, f. I-1, op. 13, d. 430, Delo po khodataistvu Voiskovogo Starshiny militsii Shabdana Dzhantaeva ob utverzhdenii za nim zemel'nogo uchastka iz chisla zemel' nakhodiashchikhsia v bezsrochnom obshchestvennom pol'zovanii kochevnikov v 400 desiatin v polnuiu sobstvennost' [File on petition of militia lieutenant colonel Shabdan Dzhantaev on approving in his entire property a plot of land of 400 desiatina from among lands in unlimited public use of the nomadic population], 1. 43-43ob.

83. RGIA, f. 391, Pereselencheskoe upravlenie ministerstva zemledeliia [Resettlement administration of the Ministry of Agriculture], op.3, d.925, Delo ob otvode v sobstbennost' voiskovomu starshine militsii Shabdanu Dzhantaevu 400 desiatin v Sarybagishevskoi volosti Pishpekskogo uezda Semirechenskoi oblasti [File on allotting 400 desiatina to militia lieutenant colonel Shabdan Dzhantaev as his property in Sarybagish volost of Pishpek uezd of Semirech'e oblast], 1. 5.

84. RGIA, f. 391, op. 3, d. 925, 1. 17-17ob.

85. RGIA, f. 391, op. 3, d. 925, 1. 19.

86. RGIA, f. 391, op. 3, d. 925, 1. 19.

87. Osobyi zhurnal soveta ministrov (SPb : 28 Sentiabria, 1910), 1-2.

88. Sh. V. "Qirğīzlar țūğrūsinda," 102.

89. TsGA RUz, f. I-1, op. 17, d.935, S perepiskoi po vodopol'zovaniiu i zemlepol'zovaniiu v Semirechenskoi oblasti [With correspondence on water use and land use in Semirech'e oblast], 1. 191ob.

90. Sh. V., "Qirḡīzlar țūğrūsinda,"102.

91. TsGA KR (Tsentral'nyi gosudarstvennyi arkhiv Kyrgyzskoi respubliki), f.77, Shabdan Dzhantaev, op. 1, d. 1, Shabdan Dzhantaev, 1.6-6ob.

92. RGVIA (Rossiiskii gosudarstvennyi voenno-istoricheskii arkhiv), f. 400, Glavnyi shtab, Aziatskaia chast' [Headquarters, Asian unit], op.1, d.3267, Delo po khodataistvu voiskovogo starshiny militsii manapa Pishpekskogo uezda, Shabdana Dzhantaeva ob otvode emu v sobstvennost zemel'nogo uchastka [File on petition of militia lieutenant colonel manap of Pishpek uezd Shabdan Dzhantaev on approving a plot of land in his entire property], 1. 83, 96.

93. Nishiyama, Roshia kakumei to Tōhō Henkyō Chiiki, 165-197. 


\section{ABSTRACTS}

Despite the imposition of Russian direct rule in 1867, the tribal chieftains bearing the title of " manap" played a dominant role as effective leaders among Kyrgyz nomads throughout the imperial period. This article investigates why manaps were able to maintain this role and how the Russian military authorities dealt with them during the half century of their direct rule. Manaps were useful in supplementing the weakness of Russian rule, and, in fact, the inadequacy of Russian governance was a key factor enabling manaps to maintain their role as the primary ruling class of Kyrgyz nomads until as late as the twentieth century. However, Russian military authorities did not actively recruit manaps as political intermediaries, but were obliged to accommodate to them. In this sense, they were in large part "passively dependent" on manaps, but did not actively protect or nurture them as a political elite.

Les manaps jouèrent un rôle majeur en tant que leaders effectifs des nomades kirghiz tout au long de la période impériale et ce, en dépit de l'imposition de l'administration directe russe en 1867. Pourquoi ces chefs tribaux furent-ils capables de conserver ce rôle et comment les autorités militaires russes traitèrent-elles avec eux durant le demi-siècle de leur administration directe ? Ce sont les objets de cette étude. L'utilité première des manaps fut de pallier les points faibles de l'administration directe russe. En effet, l'inadéquation de la gouvernance russe fut un élément clé qui permit à la classe des manaps de se maintenir dans son rôle de principale classe dirigeante des nomades kirghiz jusqu'au $\mathrm{xx}^{\mathrm{e}}$ siècle. Cependant, les autorités militaires russes ne cherchèrent pas à recruter les manaps en qualité d'intermédiaires politiques, elles durent s'en accommoder. En ce sens, on peut dire qu'elles en furent " passivement dépendantes ", mais elles ne firent rien pour les protéger ou les entretenir en tant que représentants d'une élite politique.

\section{AUTHOR}

\section{TETSU AKIYAMA}

Organization for Islamic Area Studies, Waseda University, akiyama@islam.waseda.ac.jp 